\title{
Economic Analysis Determining the Optimal Replanting Age of Date Palm
}

\author{
Hemesiri B. Kotagama ${ }^{{ }^{*}}$, Amani Juma T. Al-Alawi ${ }^{1}$, Houcine Boughanmi ${ }^{1}$, \\ Slim Zekri ${ }^{1}$, Hemanatha Jayasuriya ${ }^{2}$, and Msafiri Mbaga ${ }^{1}$
}

${ }^{1}$ Department of Natural Resource Economics, ${ }^{2}$ Department of Soils, Water and

Agricultural Engineering, College of Agricultural and Marine Sciences,

Sultan Qaboos University, P.O. Box 34, Al-Khod 123,

Sultanate of Oman

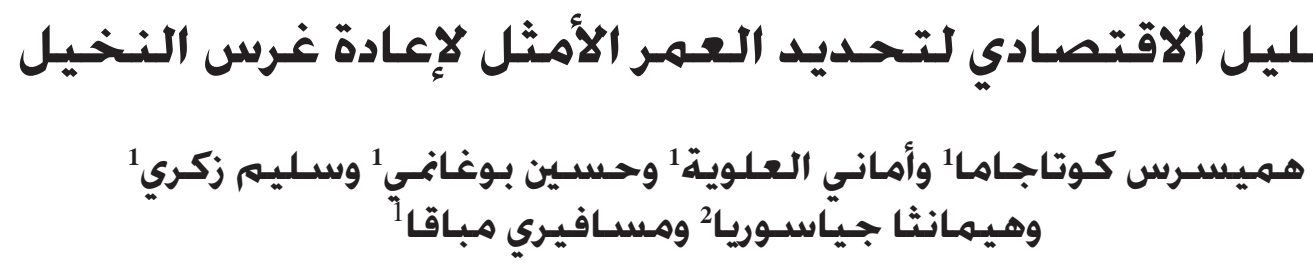

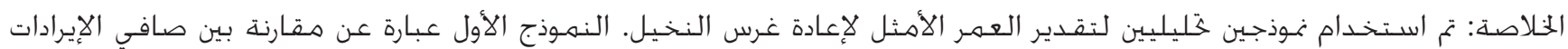

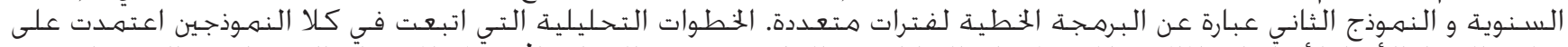

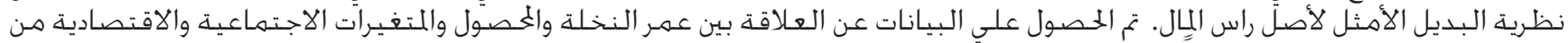

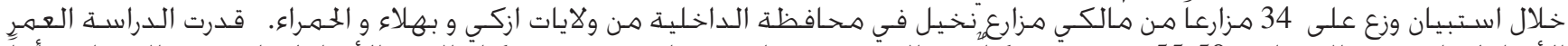

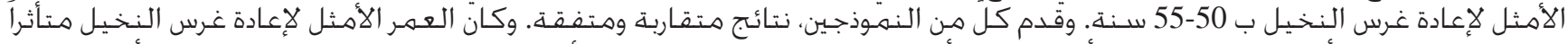

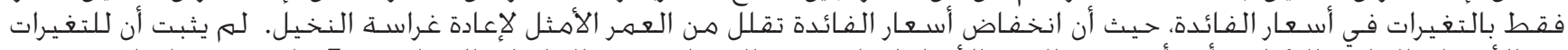

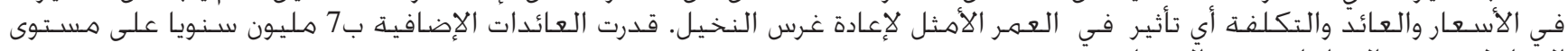

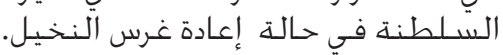

كلمات مفتاحيـة: النخـيل, إعادة الغراسـة ، البرهجـة الخطية لفترات متعددة، سـلطنة عمان

ABSTRACT: Two alternative analytical models were used to estimate the economically optimal age of replanting date palm, namely; Comparison of Equivalent Annual Net Revenue (CEAN) and Multi-Period Linear Programming Model (MPLP). Solution procedures of both models are based on the theory of optimal replacement of capital assets. Data on date palm age-yield relationship and other socioeconomic variables were gleaned through a farm survey of 34 large commercial farms, in Izki, Bahla, and Al-Hamra wilayats in the AlDakhilya governorate of the Sultanate of Oman. The study estimated the optimal age of replanting date palms as 50-55 years. Both models, CEAN and MPLP gave consistent estimates. The optimal age to replant date palms was sensitive only to changes in the interest rates. Low interest rates shortened the optimal age of date palm replanting. Changes in date price, yield and variable production costs did not change the optimal age of replanting date palms. The incremental revenue that could be accrued to the Sultanate of Oman through replanting date palms was estimated as 7 million $\mathrm{OR} /$ year.

Keywords: Date palm, replanting, Multi-Period Linear Programming, Sultanate of Oman.

\section{Introduction}

The Sultanate of Oman is ranked ninth in world date (Phoenix dactylifera L.) production with a production of 255,871 tons, which represents $3.63 \%$ of the world production (FAOSTAT, 2010). Date palms occupy about $42 \%$ of the total agricultural land in the Sultanate of Oman. Since the year 2000 date production has declined. Some factors that have contributed to the decline of date production are the non-availability of skilled labor to carry out field operations, occurrence of pests and diseases, harvest and post-harvest loses and degradation of soil and water quality (Al-Yahyai, 2007). The Government of the Sultanate of Oman since 2009 has embarked on a programme of planting one million date palm trees, to rejuvenate the date sector.

The planting of date palms could either be on new lands, or by the replanting of old unproductive date palms in existing agricultural lands. Replacing of unproductive old plants with new plants (commonly referred to as replanting) 
is an agronomic practice in perennial crop management to maximize and sustain income overtime. Further replanting does not require substantial incremental resources than presently committed. This is particularly important in the Sultanate of Oman where water is extremely scarce. Replanting date palms provides an opportunity to use the presently committed resources and improve farms towards economic production systems, which will improve the livelihood of farm dependents and increase the contribution to the nation's national income. However, the agronomic practice of replanting date palms has not been formally adopted and promoted in the Sultanate of Oman. This study has estimated the economically optimal age to replant date palms in the Sultanate of Oman.

The second section of the paper presents a review of literature on analytical methods used to estimate optimal age of replanting of perennial crops. The third section presents the analytical methodology adopted in this study to estimate the optimal age to replant date palms. The fourth section presents the results. The final section summarizes findings and draws conclusions and recommendations towards improving date palm farm income through optimal replanting in the Sultanate of Oman.

\section{Review of Literature}

Faris (1960) is a widely quoted source that has proposed analytical techniques to determine the optimum replacement age of assets. The author has presented decision rules that could be followed in deciding the replacements of assets that have (1) a short production period with revenue being realized by the sale of the asset (example: buying and selling feeder cattle); (2) a long production period with revenue being realized by the sale of the asset (example: forestry); (3) a long production period with revenues being realized throughout the life of the asset (example: perennial crops). A long production period with revenues being realized throughout the life of the asset best represents date palm plantations. The rule of replanting for such crop assets as Faris (1960) derived was that; the optimum replanting age is the age that makes the annual net revenue from "present" palms equal to the anticipated amortized present value of the net revenue from the "future" palms (replanted palms). The amortized present values of the net revenue of the future palms are obtained on the accumulated present values of net revenues over sequence of years. Perrin (1972) has through mathematical derivations confirmed on a continuous time scenario the principles of decision making on asset replacement that was proposed by Faris (1960) on a discrete scenario.

The decision criteria on asset replacement proposed by Faris (1960) and Perrin (1972) has been applied to estimate the replanting age of plum trees considering stochasticity of yield (Ward and Farris, 1968). They have compared a stochastic model based on dynamic programming with a deterministic model and have concluded that both models provided essentially the same estimate of replanting age. The study has estimated that low producing plum trees should be replanted in 24 years with the same variety of plants. A similar study determining optimal replacement age of beef cows using stochastic models has been reported by Bentley et.al. (1976).

Kearnev (1994) has used an inter-temporal linear programming model for a pip fruit orchard replacement decisions in New Zealand under changes of market conditions and technical advances. The replacement decisions resulted in an increase of the orchard's gross margin substantially. Lower interest rates were found to shorten the replanting age. A similar study has been conducted by Oppenheim (2003) using multi-period linear programming to evaluate orchard (apple and pear) adjustment strategies in New Zealand.

Etherington (1977) has used a stochastic model to determine the optimal replacement of rubber trees in Peninsular Malaysia. The model is based on the principles of deterministic asset replacement proposed by Perrin (1972). Groenewald and Dutoit (1985) used a deterministic model of asset replacement and estimated the optimal age of replanting of avocado in orchards as 18 years. It is reported that new technology that increases net returns shortens the replanting age whilst it is also sensitive to inflation. White (1986) using a dynamic programming framework and Larry et.al. (1990) using procedure and principles proposed by Faris (1960) have developed computer software models to determine the optimal age of orchard crops. Mwinjaka et.al. (1999) used a backward method dynamic programming model to determine the replacement age of coconut palms in Tanzanian farming systems. The results showed that coconut palms should be replanted when the palms are at the age between 60-80 years to obtain maximum net-returns over time. Al-Shuaibi (2001) developed a model that could explain the factors that affect the decision of date growers to plant new palms using new lands or replanting the old date orchards. The study reports that initially, young palms with less than 15 years of age have low production, then production begin to increase substantially and reaches a peak production of 75 $\mathrm{kg}$ per palm with an age of 25 years after which the yield declines with increasing age of date palms.

Ismail and Mamat (2002) have estimated the optimal age of oil palm replanting in Malaysia using a deterministic model. They have estimated that the optimal age to replant oil palms is between 25-26 years. The age of replanting decreases with price increases of palm oil. Cembalo (2002) has developed a multi-period mathematical model to account for perennial crop decisions such as replanting, storage, marketing and financial investments. The variability of returns has been incorporated by introducing a quadratic objective function that accounts for uncertainty of perishable crop production and marketing and the possible risk-averse behavior of the owner-managers. Finally, the multi-period structure of the model and risk concerns are embedded in a multi-objective framework 
reflecting the conflicting objectives tree-crop managers often pursue. The model has been used to empirically analyze a farm in Salerno province in Italy. Thang et.al. (2009) investigated the optimal replanting rule for coffee in Vietnam using a fixed-form optimization approach. The paper also has provided a detailed review of programming techniques that have been and could be potentially used to analyze multi-period optimization problems.

One of the most challenging aspects in estimating the optimal replanting age of perennial crops is establishing the age-yield relationship. Ideally agronomic experiments under a controlled situation would provide credible information. However, such data is rarely available and is a major limitation to empirical estimation of the optimal age forreplanting of perennial crops such as date palm. Ward and Faris (1968) in their investigation on replanting policies for plum trees have collected data from plum tree farmers in California. They collected data of only a single variety of plums (Santa Rosa) to avoid the problem of yield differences between varieties. Data had been collected through personal interviews with farmers. A deficiency in data collection has been realized because farmers have already replanted the old trees and were unable to provide data about old trees. Another problem has been that even individual blocks in the plantation had trees of different age groups. Further the amounts harvested have depended upon the prevailing prices. Cembalo (2002) recorded data of a farm that had kept data on age-yield relationship consistently over time. The study by Mwinjaka et.al. (1999) on determining the optimal age for replanting coconuts in Tanzania collected data on ageto-yield relationship by taking a physical count of nuts in samples of plants (592 plants) of different age groups (1 to 90 years).

\section{Analytical Methods}

Two alternative analytical methods, that are based on principles of decision making on asset replacement were used in this study to estimate the optimal replanting age of date palms. These methods are referred to as the Comparison of Equivalent Annual Net revenues (CEAN) and the Multi-Period Linear Programming (MPLP) model. The analysis of the CEAN model is restricted to data related to a single palm whilst the MPLP model is able to analyze a whole date palm farm with palm-trees of different ages.

\section{Comparison of Equivalent Annual Net Revenues (CEAN) Model}

The principles on decision making of asset replacement that were proposed by Faris (1960) have been mathematically elucidated by Perrin (1972). Etherington (1977) has applied Perrin's (1972) mathematical exposition on principles to decision making of asset replacement, to analyses of decision making of the replanting of rubber trees. This study has adopted Etherington's (1977) exposition to explain the economic principles of deciding the age of replanting of date palms. For a life period of a date palm, which yields over years, the present value of the flow of net revenues is given by equation (1).

$$
C(0, s, 1)=\int_{0}^{s} R(t) e^{-\rho t} d t+M(s) e^{-\sigma^{s}}
$$

Where $C(0, s, 1)$ is the present value of the flow of net revenues from a life period ' 1 ' of a palm planted in year ' 0 ' and replaced in year/age ' $\mathrm{s}$ ' by a series of ' $\mathrm{m}$ ' trees. The flow of net revenues consists of net revenues over ' $t$ ' years and a salvage value $M(s)$. $\rho$ the interest rate. For a series of life periods the replanting problem is to find 's' that maximizes the present value of the net revenues as given in equation (2) over a series of life periods up to infinity ' $\infty$ '.

$$
C(0, s, \infty)=C(0, s, 1)+e^{-\rho^{s}} C(0, s, 1)+e^{-\rho^{\iota s}} C(0, s, 1)+
$$

The series in equation (2) reduces to equation (3) as the number of life periods tends to infinity.

$$
C(0, s, \infty)=\frac{1}{1-e^{-\rho^{s}}} C(0, s, 1)
$$

In order to find 's' the replanting age at which the net revenues over time is maximized the first derivative of equation (3) is maximized to get equation (4).

$$
\left[R(s) M^{\prime}(s)\right] e^{-\rho s}\left[\int_{0}^{s} R(t) e^{-\rho^{t}} d t M(s)\right] \frac{\rho}{e^{\rho^{t}}-1}
$$

Equation (4) is that discounted marginal net revenue which is equal to the annuity formed from the discounted total flow of net revenues from date yields plus the salvage value of the tree. The annuity is equivalent to the average annual earnings over years to infinity. Thus equation (4) states that marginal and average net revenues are equal or average annual net revenues are maximized. Equation (4) can be presented as equation (5) considering discrete age and thus discrete interest rate ' $r$ '.

$$
[R(s)+\Delta M(s)]=\left[\sum_{0}^{s} R(t)(1+r)^{-t}+M(s)\right] \frac{r}{(1+r)^{s}-1}
$$

If the salvage value is ignored then equation (5) can be presented as equation (6) which states that the optimal age of replanting is where the discounted marginal net revenues (MNR) are equal to the annuity formed from the discounted total flow of net revenues (ANR) from date palm yields of palms replanted over years. Information of

$$
[R(s)](1+r)^{-s}=\left[\sum_{0}^{s} R(t)(1+r)^{-t}\right] \frac{r}{(1+r)^{s}-1}
$$




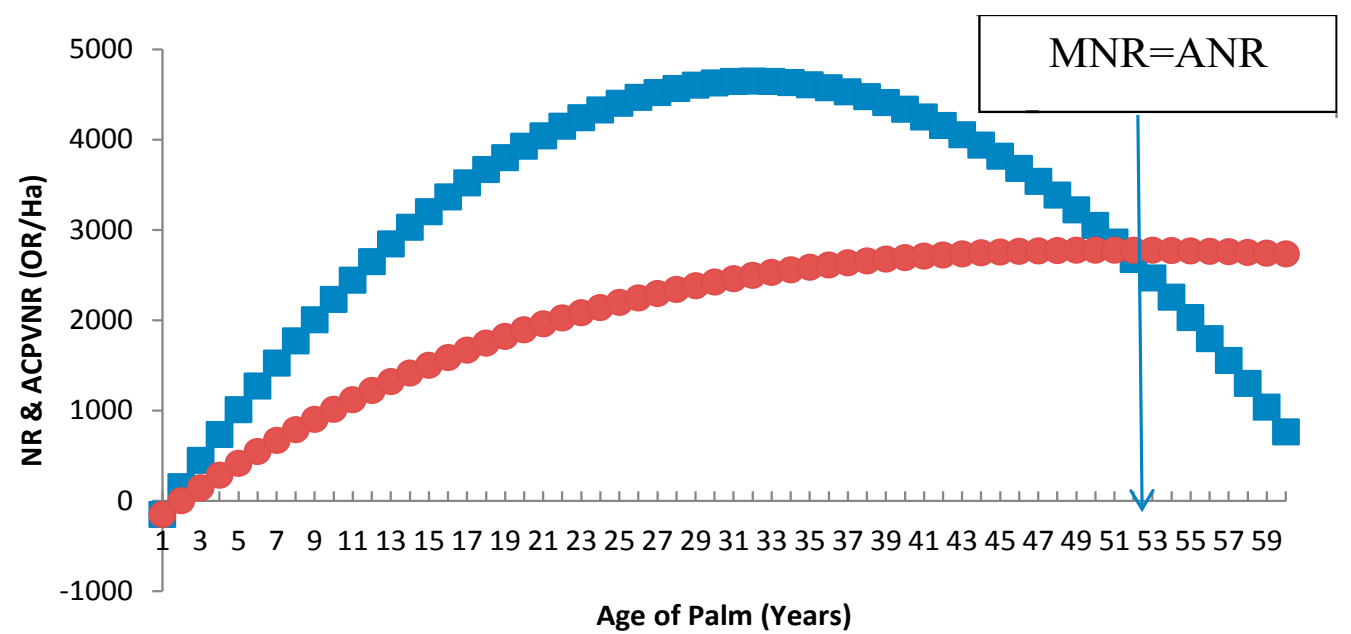

$-\mathrm{NR}(\mathrm{OR} / \mathrm{Ha})-\mathrm{ACPVNR}(\mathrm{OR} / \mathrm{Ha})$

Figure 1. Principle on determining the optimal replanting age of a perennial crop.

equation (5) is portrayed in figure 1. According to figure, 1 if MNR of the existing palm at an age of the palm is higher than the ANR from replanting the palm then the existing palm should not be replanted and if MNR of the existing palm at an age of the palm is lower than the ANR from replanting the palm then the existing palm should be replanted. An Excel spreadsheet model was developed to generate information for equation 6 to compare MNR and ANR and determine the optimal age of replanting.

As per the model developed above (equation 6) on deriving the decision rule on date palm replanting, the data required to solve the model are age-yield relationship of date palms, net returns from dates (thus input use quantities and prices, date prices) and the interest rate. The age-yield relationship need to be considered for the existing palm and the potential palm that would be replanted. The age-yield relationship represents the technology in terms of the variety of the date palm. If the same variety is considered for replanting, the age-yield relationship will be the same for estimating MNR and ANR. If a technologically improved variety is considered for replanting then the MNR would be for the existing palm and the ANR would be of the improved variety. In this study the age yield relationship for date palm is considered as having a 60 year life which is considered in 12 age categories of 5 years each.

\section{Multi-Period Linear Programming (MPLP) Model}

Agricultural decision making about perennial crops in particular is characterized with multiple year dynamics, where a present decision influences future decisions (McCarl and Spreen, 1997). In this study the decision to replant or (not-replant) date palm in a given year (i.e. the time path of replanting) has an influence on the future flow of net revenue from date palms.
Multi Period Linear Programming Models (MPLP) are widely known and have been used in agricultural systems modeling (Hazel and Norton, 1986). MPLP models recognize inter temporal linkages in farm activities and maximize the net present value of profit (or an appropriate objective) given constraints of resources overtime. Each time period is linked through availability of resources and activities as appropriate. In designing MPLP models decisions ought to be taken on, the length of the time horizon, the length of intervals within the time horizon, the rate of inter-temporal time preference (interest rate) and risk conditions if such is to be considered in decision making (Cembalo, 2002). There exist tradeoffs between these choices in terms of complexity, largeness and convenience of solving models. The choice and justification of an interest rate in multi-period models is crucial and it depends on several factors such as measures of real and nominal interest rates, opportunity cost of capital, returns from alternative investments, considerations of risk and personal time preferences. Salvage values are typically estimated and included by capitalizing the net returns beyond the final year of the model. Non-inclusion of salvage values would bias solutions to investing in early periods (Cembalo, 2002).

The structure of the model used in this study to determine the optimal age of replanting date palms and also to determine the optimal replanting schedule for farms in Oman is based on the generalized MPLP model structure proposed by McCarl and Spreen (1997) and is explained below.

Maximize:

$$
\sum_{t} \sum_{e \leq k}(1+r)^{-t} C_{e} X_{t, e}
$$


Subject to:

$$
\begin{aligned}
& \sum_{e \leq k} A_{i e} X_{t, e} \leq b_{i t} \text { for all } i \text { and } t \\
& X_{0, e}=X_{0, e}^{*} \text { for } e<K \\
& -X_{t-1, e-1}+X_{t, e} \leq 0 \text { for all } t \text { and } e>0 \text { and } e \leq K \\
& X_{t, e} \geq 0 \text { for all } t, e .
\end{aligned}
$$

Where Equation (7) is the objective function which maximizes the present value of the net revenue of date palm of different ages over years. Equation (8) constraints the resource use for date palm cultivation to resource availability. Equation (9) specifies the initial inventory, i.e. areas of date palm of different ages that exists in the farm. Equation (10) transfers date palm age cohorts of a time period to the next time period sequentially as date palms age. The equation (11) specifies non-negativity of the decision variables, i.e. area of date palms.

The specification of variables is as follows:

$X_{1, e}$ is the decision variable viz; area of land under palms $t$ (age intervals) under cultivation of elapsed age e. $t: t_{1} \ldots$ $t_{12}$; The segregation of age of date palms (60 years) into 12 intervals of 5 years each is done to keep the model within limits of manageability, whilst being practically useful in decision making on replanting of date palm. $e: e_{1} \ldots e_{12}$; discrete time representation is used in 12 time periods of 5 year intervals resulting in 60 years. Since the objective is to determine the time path of replanting (i.e., to determing at what age the palms should it be replanted) a sufficient age is necessary to allow for adjustment which needs to be incorporated in the model structure. Yearly specification would make the model excessively large.

$r$ : The interest used is $4 \%$.

$C_{e}$ : Net revenue per unit of land at different ages of the date palm, are the same values derived and used in the CEAN model (estimated based on age-yield relationship, input use and prices and product price).

$A_{i e}$ : The resource use $\mathrm{A}_{\mathrm{ie}}$ is considered in terms per unit land.

$i$ : Only land is considered as a constraint. This because the main objective of the model is to determine the optimal replanting schedule for an existing farm and it is considered that replanting does not require substantial additional resource commitments other than resources used for the existing date palm.

$b_{i t}$ : The availability of land is the average farm size as found through the farm survey.

$K$ : The life of a palm is considered as 60 years.

$X_{0, e}^{*}$ : The initial inventory of age distribution of date palms in farms as found through the farm survey is used in the model to determine the replanting schedule for existing farms vis-à-vis new farms where it is the total availability of land. The Excel solver was used to solve the linear programing model.

\section{Data Collection Methods}

The core datum required for this study is the age-yield relationship of date palm varieties cultivated in the Sultanate of Oman. A survey was done to obtain the above datum through a purposive sample of farms. The sample included farmers from whom the above information could be reliably obtained, i.e., commercial date palm farms and elderly farmers who had a memory of age-yield relationship of date palms. The sample size was limited to 34 farmers given the nature of data collected that required extensive time to interview the respondents and the limitation of other resources as finance and personal.

\section{Results and Discussion}

\section{Farming System and Agronomic Practices}

The survey was conducted in three wilayats from AlDakhilya Governorate namely, Izki, Bahla, and AlHamra. The distribution of the farms among the wilayats was that Izki was represented with $44 \%$, farms, Bahla and Al-Hamra with 41 and $15 \%$ farms, respectively. The average age of farmers was 59 years. The high average age was due to purposive selection of elderly farmers. The average number of years associated with farming of the respondents was 42 years. Most $(56 \%)$ of the respondents have not had formal education.

The average farm size was estimated as 1.2 hectares. The three main date varieties that were cultivated are Khalas, Fardh and Khasab which represent 48, 20 and $11 \%$ of the palms, respectively. The average farm had 125 date palms per hectare. Date palm growers are not practicing any standard on distancing of palms; row to row and plant to plant distance varies considerably throughout the date palm farms. The average distance between date palms is about 4.2 meters. Almost all farms (98\%) had intercropped with annual and perennial crops between date palms. The most common intercrops were orange, lemon, alfalfa, garlic, onion and wheat. The most common livestock enterprises found in the surveyed farms were sheep, goats, cows and poultry (average of 6 goats per farm and one cow per farm). The most used fertilizer was animal manure. Eighty-two percent of the farmers fertilized date palm with animal manure and the average application was $49 \mathrm{~kg}$ per palm. Water use could not be quantified as the use was expressed in terms of hours of water distributed to the farm through open channels.

According to the survey, $65 \%$ of the farmers said that they have replanted their date palms in the past. Lack of awareness of the age of plant, lack of water and lack of space are the justifications for not replanting by those who had not replanted. The number of date palms that had been replanted in the past ranges from minimum of 
1 date palm to maximum of 30 palms replanted per farm. Morphological characteristics, more specifically height of the date palm, was the main factor that was considered in deciding to replant a palm. The height of the palm relates to the labor intensive practices of pollination and harvesting. Hence farmers consider the incremental costs associated with height of palm when deciding when to replant. Fifty-three percent of the respondents replant when the harvesting is not feasible because of excessive height of palms. The other reasons that influenced the decision to replant are declining yield with age in terms of reduced number of bunches, reduced number of fruits per bunch, reduced quality of the fruit and the effect of reduced prices of different varieties.

There also prevails a perception among farmers that, as the age of the date palms increase, the better will be the fruit quality. Thirty-five percent of the farmers mentioned that the quality of the date fruit change with the increased age of the palm. Among these 35\% farmers, 50\% said that the quality will be better as the age increases, while the remaining 50\% said that as age increases the quality of the fruit will decrease in terms of size and color.

Fifty percent of the farmers who replanted date palm had used new date palm varieties to replace the old palm. Khalas dominates the varieties that farmers use to replant the old varieties. Better quality and price are the factors that influence farmers' decisions in the choice of this variety. Some farmers retain 'suckers/ off shoots' from the mother palm, whilst inducing the mother palm to decay. Majority of the farmers do not make any use of the old palm trunks.

The farm survey data indicated that $48 \%$ of the palms in the sample farms were Khalas variety. Almost all (99\%) the palms are less than 50 years and about $95 \%$ are less
Table 1. Age-yield relationship for Khalas date variety.

\begin{tabular}{ccc}
\hline \multirow{2}{*}{ Age of palm $(\mathrm{yrs})$} & \multicolumn{2}{c}{ Yield $(\mathrm{kg} / \mathrm{palm})$} \\
\cline { 2 - 3 } & Survey & Predicted \\
\hline 1 to 5 & 59.4 & 62.3 \\
6 to 10 & 89.5 & 102.0 \\
11 to 15 & 187.2 & 133.7 \\
16 to 20 & 131.7 & 157.2 \\
21 to 25 & 150.0 & 172.7 \\
26 to 30 & 148.0 & 180.0 \\
31 to 35 & 207.5 & 179.3 \\
36 to 40 & 218.0 & 170.5 \\
41 to 45 & 120.0 & 153.6 \\
46 to 50 & 144.0 & 128.6 \\
51 to 55 & $\mathrm{NR}^{*}$ & 95.6 \\
56 to 60 & $\mathrm{NR}^{*}$ & 54.4 \\
\hline
\end{tabular}

*NR indicates not reported by farmers in the sample.

than 40 years of age. More than $50 \%$ of the palms are less than 20 years in age. This could be due to the fact that the large commercial farms have been cultivated post 1970s.

\section{Base Data Used in CEAN and MPLP Models}

The age-yield data for Khalas as found through the sample survey is given in table 1 . The average yield is higher than nationally reported yields of $45 \mathrm{Kg} / \mathrm{Palm}$, since the sample was purposive and represented large commercial farms. Using the data in table 1 a best-fit curve on the age-yield relationship of the Khalas date variety was estimated (Fig. 2). The equation of the best fit on the age-yield relationship was used to re-estimate the ageyield relationship of the Khalas date variety (Table 1).

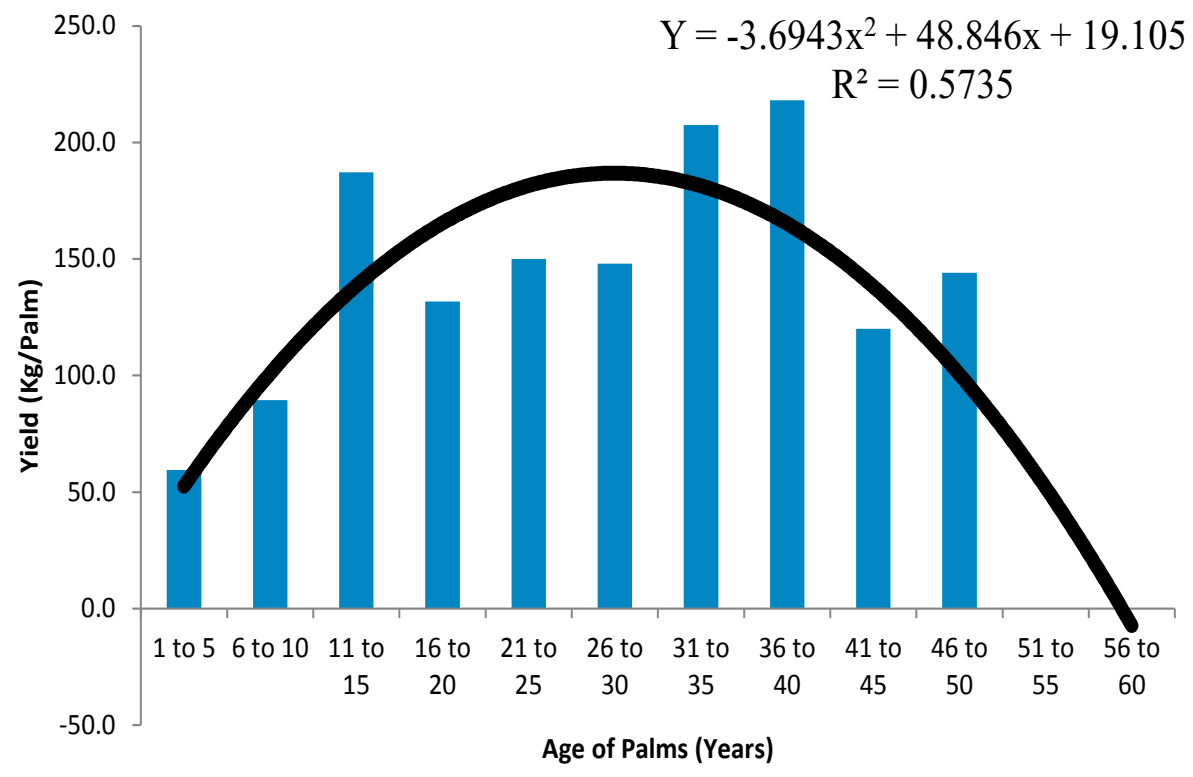

Figure 2. Age-yield relationship of Khalas date variety and the estimated function. 


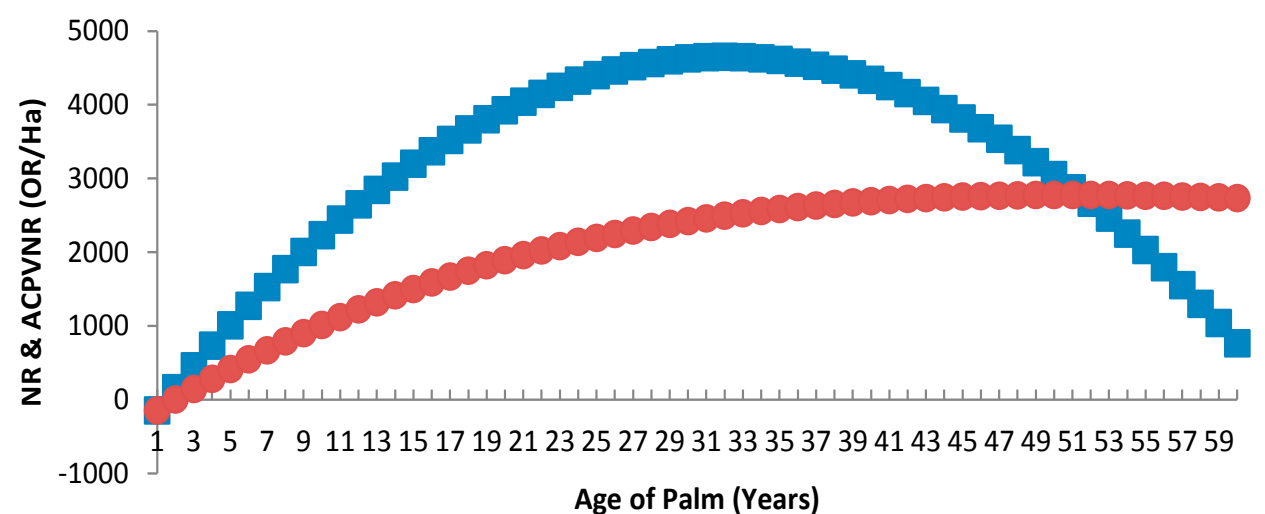

Age of Palm (Years)

$-\mathrm{NR}(\mathrm{OR} / \mathrm{Ha}) \quad \mathrm{ACPVNR}(\mathrm{OR} / \mathrm{Ha})$

Figure 3. Results of the base model with age-yield relationship of Khalas variety.

Number of palms per hectare was considered as 125 as found through the survey. It was considered that the same variety (Khalas) is replanted, hence the same age-yield relationship was considered for the potential replanting palms. Sensitivity analysis for an increase and decrease of $25 \%$ of the base yield was done.

Using the average price of dates over the period 1961 to 2011 in the Sultanate of Oman, as reported in FAO statistics, a trend line on price prediction was estimated. Based on the trend line the predicted price of $0.250 \mathrm{OR} / \mathrm{Kg}$ was considered as the base price. A decrease and increase of $25 \%$ of the base price was considered for sensitivity analysis. The cost of production estimate of 914 OR/ha for date palm cultivation provided by the Ministry of Agriculture and Fisheries Wealth, Sultanate of Oman was used as base cost. An increase and a decrease of cost by $25 \%$ were considered for sensitivity analysis. A $4 \%$ interest rate was used in the study based on the average for the period 2002 to 2010 of the interest rate spread of the Sultanate of Oman as reported by the World Bank. Sensitivity analysis was done for 1 and $10 \%$ interest rates.

\section{Results from CEAN Model Analysis}

The estimated optimal age for replanting of existing Khalas date variety with the same variety under base data of yield, price, interest rate and cost is given in figure 3 . The results of the sensitivity analysis are given in table 2. It is estimated that on base conditions the optimal age to replant is 52 years. The optimal age of replanting is

Table 2. Results on optimal age of replanting and sensitivity analysis for Khalas variety: CEAN Model.

\begin{tabular}{|c|c|c|c|c|c|c|c|c|c|}
\hline \multirow{3}{*}{ Factors } & \multirow{3}{*}{$\begin{array}{l}\text { Base } \\
\text { model }\end{array}$} & \multicolumn{8}{|c|}{ Sensitivity analysis } \\
\hline & & \multicolumn{2}{|c|}{ Price change } & \multicolumn{2}{|c|}{ Cost change } & \multicolumn{2}{|c|}{ Interest change } & \multicolumn{2}{|c|}{ Change in yield } \\
\hline & & $\begin{array}{l}\text { Increase } \\
\text { by } 25 \%\end{array}$ & $\begin{array}{c}\text { Decrease } \\
\text { by } 25 \%\end{array}$ & $\begin{array}{l}\text { Increase } \\
\text { by } 25 \%\end{array}$ & $\begin{array}{c}\text { Decrease } \\
\text { by } 25 \%\end{array}$ & $\begin{array}{l}\text { Increase } \\
\text { to } 10 \%\end{array}$ & $\begin{array}{c}\text { Decrease } \\
\text { to } 1 \%\end{array}$ & $\begin{array}{l}\text { Increase } \\
\text { by } 25 \%\end{array}$ & $\begin{array}{c}\text { Decrease } \\
\text { by } 25 \%\end{array}$ \\
\hline Age (yr) & 60 & 60 & 60 & 60 & 60 & 60 & 60 & 60 & 60 \\
\hline $\begin{array}{l}\text { Average yield } \\
\text { (kg/yr/tree) }\end{array}$ & 132 & 132 & 132 & 132 & 132 & 132 & 132 & 165 & 99 \\
\hline $\begin{array}{l}\text { Average yield } \\
(\mathrm{kg} / \mathrm{ha})\end{array}$ & 16450 & 16450 & 16450 & 16450 & 16450 & 16450 & 16450 & 20561 & 12336 \\
\hline Price (OR/kg) & 0.25 & 0.31 & 0.19 & 0.25 & 0.25 & 0.25 & 0.25 & 0.25 & 0.25 \\
\hline $\begin{array}{l}\text { Average gross } \\
\text { return (OR/ha) }\end{array}$ & 4111 & 5261 & 3225 & 4111 & 4111 & 4111 & 4111 & 5141 & 3084 \\
\hline $\begin{array}{l}\text { Average cost } \\
(\mathrm{OR} / \mathrm{ha})\end{array}$ & 914 & 914 & 914 & 1142 & 686 & 914 & 914 & 914 & 914 \\
\hline $\begin{array}{l}\text { Average net } \\
\text { return }(\mathrm{OR} / \mathrm{ha})\end{array}$ & 3197 & 4186 & 2210 & 2969 & 3427 & 3197 & 3197 & 4226 & 2170 \\
\hline Interest & 0.04 & 0.04 & 0.04 & 0.04 & 0.04 & 0.10 & 0.01 & 0.04 & 0.04 \\
\hline $\begin{array}{l}\text { Age of } \\
\text { replanting }(\mathrm{yr})\end{array}$ & 52 & 52 & 52 & 52 & 52 & 56 & 49 & 52 & 52 \\
\hline
\end{tabular}


Table 3. Results on optimal age of replanting and sensitivity analysis for Khalas date palm: MPLP Model.

\begin{tabular}{|c|c|c|c|c|c|c|c|c|c|}
\hline \multirow{3}{*}{ Factors } & \multirow{3}{*}{$\begin{array}{r}\text { Base } \\
\text { model }\end{array}$} & \multicolumn{8}{|c|}{ Sensitivity analysis } \\
\hline & & \multicolumn{2}{|c|}{ Price } & \multicolumn{2}{|c|}{ Cost } & \multicolumn{2}{|c|}{ Interest } & \multicolumn{2}{|c|}{ Yield } \\
\hline & & $\begin{array}{l}\text { Increase } \\
\text { by } 25 \%\end{array}$ & $\begin{array}{r}\text { Decrease } \\
\text { by } 25 \%\end{array}$ & $\begin{array}{l}\text { Increase } \\
\text { by } 25 \%\end{array}$ & $\begin{array}{r}\text { Decrease } \\
\text { by } 25 \%\end{array}$ & $\begin{array}{r}\text { Increase } \\
\text { to } 10 \%\end{array}$ & $\begin{array}{r}\text { Decrease } \\
\text { to } 1 \%\end{array}$ & $\begin{array}{l}\text { Increase } \\
\text { by } 25 \%\end{array}$ & $\begin{array}{r}\text { Decrease } \\
\text { by } 25 \%\end{array}$ \\
\hline Age (yr) & 60 & 60 & 60 & 60 & 60 & 60 & 60 & 60 & 60 \\
\hline $\begin{array}{l}\text { Average yield } \\
(\mathrm{kg} / \mathrm{yr} / \mathrm{tree})\end{array}$ & 132 & 132 & 132 & 132 & 132 & 132 & 132 & 165 & 99 \\
\hline $\begin{array}{l}\text { Average yield } \\
(\mathrm{kg} / \mathrm{ha})\end{array}$ & 16450 & 16450 & 16450 & 16450 & 16450 & 16450 & 16450 & 20561 & 12336 \\
\hline Price $(\mathrm{OR} / \mathrm{kg})$ & 0.25 & 0.31 & 0.19 & 0.25 & 0.25 & 0.25 & 0.25 & 0.25 & 0.25 \\
\hline $\begin{array}{l}\text { Average gross } \\
\text { return (OR/ha) }\end{array}$ & 4111 & 5261 & 3226 & 4111 & 4111 & 4111 & 4111 & 5141 & 3084 \\
\hline $\begin{array}{l}\text { Average cost } \\
(\mathrm{OR} / \mathrm{ha})\end{array}$ & 914 & 914 & 914 & 1142 & 686 & 914 & 914 & 914 & 914 \\
\hline $\begin{array}{l}\text { Average net return } \\
(\mathrm{OR} / \mathrm{ha})\end{array}$ & 3197 & 4187 & 2210 & 2969 & 3427 & 3197 & 3197 & 4226 & 2170 \\
\hline Interest & 0.04 & 0.04 & 0.04 & 0.04 & 0.04 & 0.10 & 0.01 & 0.04 & 0.04 \\
\hline $\begin{array}{l}\text { Age of replanting } \\
(\mathrm{yr})\end{array}$ & 55 & 55 & 55 & 55 & 55 & 55 & 50 & 55 & 55 \\
\hline
\end{tabular}

sensitive only to the interest rate. A decrease in the interest rate $(1 \%)$ shortens optimal replanting age to 49 years and an increase in the interest rate $(10 \%)$ lengthens the optimal replanting age to 56 years.

Table 4. Approximate estimates of age of date palm plantations in the Sultanate of Oman.

\begin{tabular}{lccc}
\hline Year planted & $\begin{array}{c}\text { Present age } \\
\text { of plantation } \\
\text { (yrs) }\end{array}$ & $\begin{array}{c}\text { Area } \\
\text { harvested } \\
\text { (ha) }\end{array}$ & $\begin{array}{c}\text { Area } \\
\text { planted } \\
\text { (ha) }\end{array}$ \\
\hline Before 1960 & $>51$ & 13000 & 13000 \\
$1961-1965$ & $46-50$ & 13000 & 0 \\
$1966-1970$ & $41-45$ & 13000 & 1000 \\
$1971-1975$ & $36-40$ & 14000 & 6100 \\
$1976-1980$ & $31-35$ & 20100 & 1900 \\
$1981-1985$ & $26-30$ & 22000 & 3000 \\
$1986-1990$ & $21-25$ & 25000 & 4000 \\
$1991-1995$ & $16-20$ & 29000 & 6508 \\
$1996-2000$ & $11-15$ & 35508 & 0 \\
$2001-2005$ & $5-10$ & 31353 & 0 \\
$2006-2010$ & $<5$ & 31353 & 0 \\
\hline
\end{tabular}

\section{Results from MPLP Model Analysis}

The MPLP model was solved for base data and then sensitivity analysis was done on price, yield and interest rate changes, similar to the analysis with the CEAN model. The results are reported in table 3 . In reporting the results of the MPLP model analysis, the upper value of the range of the period is reported. The CEAN and MPLP models have produced consistent results on the estimation of the age of replanting (compare Tables 2 and 3). Considering results of both models and results of sensitivity analysis on price, cost, interest and yield changes it could be concluded that date palms should be replanted at about $50 \mathrm{yrs}$.

\section{Replanting Schedule for Date Palm Plantations in Oman}

Data on age distribution of date palm plantation in the sultanate of Oman is not available. An estimation was made using the FAO STAT data that has reported area harvested by year. The yearly data on area harvested was averaged for 5 year periods and reported in table 4 . The incremental area planted during a period (period $n)$ is estimated by deducting area harvested in period $n$ from area harvested in period $n+1$ (every period is considered as 5 years). The area planted with date palms at a given period increases the area harvested after 5 years as fruiting occurs after 5 years of planting. It is estimated that from the area of date palms in year 2000 (35508 ha) at least 14000 ha (or about 40\%) is older than 40 years. From 2000 to 2010 the area has decreased down to 31353 ha. 
Table 5. Optimal age distribution schedule of date palm plantations in Oman.

\begin{tabular}{|c|c|c|c|c|c|c|c|c|c|c|c|c|}
\hline \multirow{2}{*}{$\begin{array}{l}\text { Year/ } \\
\text { period }\end{array}$} & \multicolumn{12}{|c|}{ Date palm area (ha) by age (yrs) } \\
\hline & $0-5$ & $5-10$ & $11-15$ & $16-20$ & $21-25$ & $25-30$ & $31-35$ & $36-40$ & $41-45$ & $46-50$ & $51-55$ & $56-60$ \\
\hline 2010-2015 & 13000 & 0 & 0 & 6508 & 4000 & 3000 & 1900 & 6100 & 1000 & 0 & 0 & 0 \\
\hline 2016-2020 & 0 & 13000 & 0 & 0 & 6508 & 4000 & 3000 & 1900 & 6100 & 1000 & 0 & 0 \\
\hline 2021-2025 & 1000 & 0 & 13000 & 0 & 0 & 6508 & 4000 & 3000 & 1900 & 6100 & 0 & 0 \\
\hline 2026-2030 & 6100 & 1000 & 0 & 13000 & 0 & 0 & 6508 & 4000 & 3000 & 1900 & 0 & 0 \\
\hline 2031-2035 & 4900 & 6100 & 1000 & 0 & 13000 & 0 & 0 & 6508 & 4000 & 0 & 0 & 0 \\
\hline $2036-2040$ & 4000 & 4900 & 6100 & 1000 & 0 & 13000 & 0 & 0 & 6508 & 0 & 0 & 0 \\
\hline 2041-2045 & 6508 & 4000 & 4900 & 6100 & 1000 & 0 & 13000 & 0 & 0 & 0 & 0 & 0 \\
\hline 2046-2050 & 0 & 6508 & 4000 & 4900 & 6100 & 1000 & 0 & 13000 & 0 & 0 & 0 & 0 \\
\hline 2051-2055 & 0 & 0 & 6508 & 4000 & 4900 & 6100 & 1000 & 0 & 13000 & 0 & 0 & 0 \\
\hline 2056-2060 & 0 & 0 & 0 & 6508 & 4000 & 4900 & 6100 & 1000 & 0 & 13000 & 0 & 0 \\
\hline 2061-2065 & 0 & 0 & 0 & 0 & 6508 & 4000 & 4900 & 6100 & 1000 & 0 & 13000 & 0 \\
\hline $2066-2070$ & 13000 & 0 & 0 & 0 & 0 & 6508 & 4000 & 4900 & 6100 & 1001 & 0 & 0 \\
\hline
\end{tabular}

The MPLP model was used to estimate the replanting schedule (area to replant by periods) for the Sultanate of Oman by considering the present age distribution of palms in the Sultanate of Oman (Table 4) as initiating data and considering a 35508 hectares of date plantations in the Sultanate of Oman, with data on age-yield relationship, prices, cost of production etc., considered as the same as of the base model. The results of the model provided the replanting schedule given in table 5. The area in hectares in the second column of the table 5 are the areas that should be replanted in the identified periods of the first column. This information on the date palm replanting schedule is reproduced as table 6 . Table 5 shows how the age classes of date palms shifts over time and gets replanted. It is noted that when considering existing palms of different ages such as in a single farm, some palms would be replanted even earlier than 50 years. Consider the column on age group 41-45 years in table 5, it is noted that 3000 ha gets replanted at age 45 along with 1900 ha at age 46-50 years. Further 4000 ha and 6508 ha too gets replanted after 41-45 years. Although the optimal age of replanting was estimated as 50 years for date palm cultivated as an age-homogenous new plantation, the optimal age for replanting of an age-heterogeneous existing plantation could be less. Thus, the MPLP model provides a more comprehensive analysis and realistic results on the optimal replanting age for whole farms. The MPLP model developed in this study could be used for developing optimal date palm replanting schedules for individual farms by extension officers, whilst considering realistic conditions resource availability and institutional capacity of implementing agencies.

The estimated (using the MPLP with base data) present value that would be generated with and without replanting existing date palm plantations in Oman (35508 ha with age distribution given in Table 4) is given in table 7. It was estimated that if date palms were replanted optimally

Table 6. Date palm replanting schedule for the Sultanate of Oman.

\begin{tabular}{cc}
\hline Year/period & Area (ha) to be replanted \\
\hline $2010-2015$ & 13000 \\
$2016-2020$ & 0 \\
$2021-2025$ & 1000 \\
$2026-2030$ & 6100 \\
$2031-2035$ & 4900 \\
$2036-2040$ & 4000 \\
$2041-2045$ & 6508 \\
$2046-2050$ & 0 \\
$2051-2055$ & 0 \\
$2056-2060$ & 0 \\
$2061-2065$ & 0 \\
$2066-2070$ & 13000 \\
\hline
\end{tabular}


Table 7. Estimated benefits of replanting date palm plantation in the Sultanate of Oman.

\begin{tabular}{lcc}
\hline Scenario & $\begin{array}{c}\text { Present value } \\
\text { (million OR) }\end{array}$ & $\begin{array}{c}\text { Amortized value } \\
\text { (million OR) }\end{array}$ \\
\hline Without replanting & 1856 & 82 \\
With replanting & 2218 & 98 \\
Benefit of replanting & 361 & 16 \\
\hline
\end{tabular}

they would generate a net revenue 2218 Million OR and if not replanted the net revenue would be 1856 Million OR in present value over 60 years and $4 \%$ interest. The benefit of replanting over not replanting is 361 Million OR in present value, which is equivalent to 16 Million OR when amortized over 60 years and $4 \%$ interest. This implies that if a replanting is undertaken as scheduled in table 6 the Sultanate of Oman could gain 16 Million OR per year in the future. However, this is an upper-bound estimate because the sample considered for this study is a purposive sample of large commercial farms reporting an average yield of $132 \mathrm{~kg} / \mathrm{palm}$. This yield is 3.5 times higher than the national average date palm yield of 45 $\mathrm{kg} / \mathrm{palm}$. Also the upper-bound estimate assumes that at present farmers do not replant date palms. However, the survey found that $65 \%$ of the farmers responded to having replanted (at least one palm) date palm in the past years. Thus this is an upper-bound estimate of the rate of replanting adopted.

Given the above reasons the upper bound value was subjected to a sensitivity analysis by considering the national average yield of $38 \mathrm{~kg} / \mathrm{palm}$ and a $65 \%$ rate of replanting as being currently adopted (Table 8 ). Thus, the average benefit from replanting date palms based on the sensitivity analysis is 7 Million OR/yr. The revenue from date palms in year 2011 in Oman was OR 52.6 million (FAO STAT, 2010). Thus replanting of date palms could increase the revenue by more than $13 \%$ over the current (2011) revenue from date palms in the Sultanate of Oman.

Table 8. Sensitivity analysis on benefits of replanting date palm in the Sultanate of Oman.

\begin{tabular}{lcc}
\hline \multicolumn{2}{c}{ Variables } & $\begin{array}{c}\text { Benefit } \\
\text { (million OR/yr) }\end{array}$ \\
\cline { 1 - 2 } Yield (kg/palm) & $\begin{array}{c}\text { Current replanting } \\
\text { rate }(\%)\end{array}$ & 16.0 \\
38.0 & 0.0 & 4.6 \\
132.0 & 0.0 & 5.6 \\
38.0 & 60.0 & 1.6 \\
\hline Average & 60.0 & 7.0 \\
\hline
\end{tabular}

\section{Conclusions and Policy Suggestions}

The study estimated the optimal age of replanting date palm as 50-55 years. The optimal age to replant date palms was sensitive only to changes in the interest rate. Low interest rates shortened the optimal age of date palm replanting. Changes in price, yield and cost did not change the optimal age of replanting date palms. This implies that the results obtained for Khalas variety could be extended to the other varieties, since the major differences among varieties is related to consumer preferences, and thus the price of the dates. It was estimated that about $37 \%$ of the date palms in the Sultanate of Oman are more than 50 years old. The study derived the optimal replanting schedule for date palm for the Sultanate of Oman given the current age distribution of date palms. On the average, the benefit of replanting date palms for the Sultanate of Oman is about OR 7 million per year. Thus, the Sultanate of Oman could increase the revenue from the date palm sector by about $13 \%$ based to the revenue of the date sector in 2010 (OR 52.6 million), by adopting the derived replanting schedule.

The study reveals the significant benefit the Sultanate of Oman could gain by initiating a national program to encourage farmers to replant old unproductive date palms. Government would also have to plan extension activities and allocate resources for such a program. Since replanting, unless well planned at the farm level would incur reductions in the farm cash flow for short periods, cash flow support through financial institutions and/or government subsidies could be considered to encourage farmers. This study considered the replanting of the Khalas date palm variety with the same variety. The models developed in this study can be used to comparatively examine the possibility to replant with other date palm varieties, that are high yielding and better quality. The government could also support farmers through a planned program of propagation of date palm and providing such high yielding varieties with modern technology such as tissue culture etc. The replanting program suggested in this study is the technical ideal. It would however be necessary to develop a replanting program that is practically feasible within constraints of technology and resources.

Two alternative analytical models based on the theory of optimal replacement of capital assets were used to estimate the optimal age of replanting of date palms: the CEAN and MPLP models. The MPDL model is analytically superior to the CEAN model as the MPLP model is able to use strengths of Linear Programming for whole-farm planning. The CEAN model could only analyze the optimal age for a single palm, whilst the MPLP could analyze a whole farm with date palms with different ages and also consider resource constraints as land, water, labor, capital, etc.

The data used for the study was restrictive in terms of the sample size and due to the adoption of purposive sampling method. This, however, was inevitable given the nature of data to be collected, particularly the age-yield relationship 
of date palm. It is recommended that agronomic research be undertaken to establish the age-yield relationship of this vital crop. A larger random sample and a more elaborate data collection process involving more financial, personnel and time resources could have improved the validity of the study. The analytical methodology adopted in the study was theoretically and operationally robust. Both models namely CEAN and MPLP models can be used by extension officers in developing date palm replanting schedules and advising farmers.

\section{Acknowledgments}

This study was funded by an Internal Research Grant provided by the Sultan Qaboos University, Sultanate of Oman, on project code IG/AGR/ECON/11/01, with Dr. Hemesiri Kotagama, Dr. Slim Zekri, and Dr. Hemanatha Jayasuriya, all from the College of Agricultural and Marine Sciences, Sultan Qaboos University.

\section{References}

Al-Shuaibi, A. 2001. The econometrics of investments in Date production in Saudi Arabia. The International Journal of Applied Economics and Finance 5:177-184.

Al-Yahyai, R. 2007. Improvement of Date palm production in the Sultanate of Oman. Acta Horticulturae 736:337-343.

Bentley, E., J.R. Waters., and C.R. Shumway. 1976. Determining optimal replacement age of beef cows in the presence of stochastic elements. Southern Journal of Agricultural Economics 8:13.

Cembalo, L. 2002. Methodological Issues in Modeling Fruit Tree Production, Working Paper n. 6/2002, http: //www.depa.unina.it/depa/wpcembalo.pdf.

Etherington, D.M. 1977. A stochastic model for the optimal replacement of rubber tree. Australian Journal of Agricultural Economics 21:40-58.

Faris, J.E. 1960. Analytical techniques used in determining the optimum replacement patter. Journal of Farm Economics 42:755-766.

FAO STAT. 2010. Food and Agriculture Organization of the United Nations. Available at: http://faostat.fao.org/. Accessed on September 1, 2010.

Groenewald, J.A. and D.C. Dutoit. 1985. Economic aspects of avocado production: orchard replacement. South African Avocado Growers' Association Yearbook 8:24-26.
Hazel, P.B.R. and R.D. Norton. 1986. Mathematical Programming for Economic Analysis in Agriculture, Macmillan Publishing Company, New York, USA.

Ismail, A. and M.N. Mamat. 2002. The Optimal Age of Oil Palm Replanting, Malaysian Palm Oil Board. P.O. Box 10620, 50720 Kuala Lumpur, Malaysia, pp 11-18. Malaysian Palm Oil Board (MPOB), 2002.

Kearnev, M. 1994. An Inter-temporal Linear Programming Model for Pip Fruit Orchard Replacement Decisions. MAF Policy Technical Paper 94/6, MAF Information Bureau, New Zealand.

Larry, L.B., G.D. Bishop, and P.J. Rathwell. 1990. A computer model for peach orchard replacement. Acta Horticulturae 276:295-299.

Mc Carl, B.A. and T.H. Spreen. 1997. Applied Mathematical Programming Using Algebraic System, E book: http://agecon2.tamu.edu/people/faculty/mccarlbruce/mccspr/thebook.pdf.

Mwinjaka, S., C. Chiduza, A.E. Temu, C. Sukume, and L. Diehl. 1999. Coconut palm replacement model for Tanzanian farming systems, Journal of Agricultural Economics and Development 3:61-70.

Oppenheim, P.P. 2003. The Evaluation of Orchard Adjustment Strategies: A Linear Programing Approach to the Development of Rural Policy in the SME Sector. Proceedings of Small Enterprise Association of Australia and New Zealand $16^{\text {th }}$ Annual Conference 2003.

Perrin, R.K. 1972. Asset replacement principles. American Journal of Agricultural Economics 54:6067.

Thang. T.C., M. Burton, and D. Mrennan. 2009. Optimal Replanting and Cutting Rule for Coffee Farmers in Vietnam. Proceedings AARES 53th Annual Conference, http://ideas.repec.org/p/ags/aare09/47638.html.

Ward, L.E. and J.E. Faris. 1968. A Stochastic Approach to Replacement Policies for Plum Trees, Giannini Foundation Monograph Number 22. University of California Division of Agricultural Sciences, Giannini Foundation of Agricultural Economics.

White, G.B. 1986. A dynamic programming computer model for orchard replacement. Acta Horticulturae 184:191-198.

World Bank. 2011. (http://www.tradingeconomics.com/ oman/interest-rate-spread-lending-rate-minus-depositrate-percent-wb-data.html).

Received: January 15, 2013

Accepted: April 28, 2013 